\title{
加圧煙制御における遮煙開口部中間的開放状態での風速測定 および測定点に関する実験的研究 \\ MEASUREMENT OF WIND VELOCITY AND POINT OF MEASUREMENT AT SMOKE PROTECT OPENING IN PRESSURIZATION SMOKE CONTROL
}

\author{
岸上昌史*, 山口純一**, 沖永誠治 ${ }^{* * *}$, 松山賢****, 松下敬幸**** \\ Masashi KISHIUE, Jun-ichi YAMAGUCHI, Seiji OKINAGA, \\ Ken MATSUYAMA and Takaynki MATSUSHITA
}

\begin{abstract}
The opening wind velocity in the room model with real size was measured for the purpose of clarifying relation between altitude side wind velocity and wind velocity perpendicular to an altitude side which is needed in order to check the performance of pressurization smoke control at the time of normal temperature. As a result, what is shown below was clarified.

1) It is that coefficient which corrects altitude side wind velocity to wind velocity perpendicular to an altitude side at the situation with dominant the static pressure is not based on the degree of door open angle, but is constant, and a minimum of 0.69 is shown.

2) The value which multiplied eight-point measurement average wind speed by 0.84 can be treated as 32 -point measurement average wind speed.
\end{abstract}

Keywords : Pressurization Smoke Control, Normal Temperature, Perpendicular Wind Velocity, Altitude Side Wind Velocity, Real Large Experiment 加圧煙制御，常温時，垂直風速，垂線面風速，実大実験

\section{1. はじめに}

特別避難階段付室の煙制御として、給気により付室圧力を高め、 付室と火災室等との間の開口部(以下、遮煙開口部)での圧力制御に より付室への煙の侵入防止(遮煙)を目的とした加圧煙制御方式があ る。この方式には階段への煙の侵入を確実に防止できること、火災 後期まで効果を発揮できることといった副次的な利点もある。

現在、想定火災を設定した上で平均圧力差や近似平均圧力差を用 いた給気量算出法例えば 1)が確立されている。また、加圧煙制御シス テムが適切な挙動を示すことを定期検查時や竣工検査時に確認する 仕組みが必要であることから、松下ら 2)により常温給気時に火災時 と同一の流れ場を形成する遮煙開口部扉開放幅の算出理論(以下、常 温確認理論)が構築され、この理論を用いた常温時の確認方法が構築 された。この確認方法では常温確認理論により算出される遮煙開口 部扉開放幅での垂直風速（火災時の遮煙開口部流量を測定面積で除

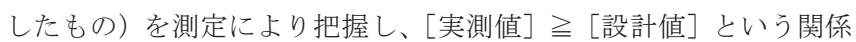
を確認する必要がある。測定方法については $0.3 \mathrm{~m}$ 角の模型を用い た外開き扉での検討 3 ) は行われているが、付室に設置される内開き 扉についての実験はなされていない。

一方、平成 21 年に告示（昭和 44 年建設省告示第 1728 号、昭和
45 年同告示第 1833 号）が改正され、加圧煙制御は特別避難階段付 室および非常用 EV 乗降ロビーに設ける排煙設備の 1 つとして使用 可能となった。告示では遮煙性能を確認するために、常温給気時に 告示で規定される遮煙開口部扉開放幅 $40 \mathrm{~cm}$ における遮煙開口部風 速を実測により把握し、[実測值] $\geqq[$ 基準風速 $V$ ]を確認する事が要 求された。基準風速 $V$ については告示で規定されているが、基準風 速と比較すべき風速測定位置は明示されていない。また、測定面の 風速ベクトルは、縮流等の影響により測定面に対して必ずしも垂直 ではないことが予想され、性能確認のためにはある測定面における 測定風速と垂直風速の関係を把握する必要がある。

ところで、遮煙開口部の風速を正確に測定するためには、測定面 を細かく分割し、多数の測定点で風速を測定することが理想的であ るが、測定の手間を考えると、少ない測定点数で遮煙開口部の風速 を安全側で把握できる簡易な測定方法が構築できれば有用である。

以上のことから、本研究では実大規模の付室に常温給気を行い、 遮煙開口部の測定面を詳細に分割して風速測定を行い、測定風速と 垂直風速の関係を明らかにするとともに、簡易測定方法の構築を目 的とする。

なお、告示を含め加圧煙制御では、一般的に動圧がほとんど寄与

\footnotetext{
* (侏)大林組技術研究所 工修

** (制大林組技術研究所 博士 (工学)

****東京理科大学総合研究機構 工修

**** 東京理科大学総合研究機構 准教授. 博士 (工学)

***** 神戸大学大学院工学研究科建築学専攻 教授・博士 (工学) 
せず(付室の十分内部の速度 $\fallingdotseq 0$ )、静圧が支配的である状況を想定す る。しかし、付室のような小規模空間に給気した場合、現状の給気 設備では動圧をすべて静圧に解消することができず、動圧が遮煙開 口部風速分布に影響を与えることが考えられる。以上のことから、 本研究では静圧が支配的な状沉を主に対象と寸るが、動圧が支配的 な場合についても検討を行う。

\section{2. 実験概要}

\section{1 実験模型}

本研究で使用した付室を図 1(a)(b)に示す。

付室(幅 $2.7 \mathrm{~m}$ 、奥行き $5.4 \mathrm{~m}$ 、高さ $3.0 \mathrm{~m}$ )の天井は $15 \mathrm{~mm}$ の強化 石膏ボード、床はコンクリート、壁は厚さ $12.5 \mathrm{~mm}$ の石膏ボードと した。壁面には給気口に近い側から開口部 $\mathrm{A}$ 、開口部 $\mathrm{B}$ (いずれも幅 $0.85 \mathrm{~m}$ 、高さ $2 \mathrm{~m}$ )を設置した。開口部には厚さ $70 \mathrm{~mm}$ の屝を設置 し、一方が開放状態のとき、他方は閉鎖状態とした。また、開口部 $\mathrm{B}$ は扉付替えにより、開放方向を変更できる。本研究では図 2 に示 すとおり、流れ方向に背を向けて開く場合を下流側開放、流れ方向 に向けて開く場合を上流側開放と定義寸る。なお、付室外部は十分 外気に開放された状態であった。また、開口部からの排出される流 れを阻害する障害物はなかった。

加圧給気系は、風量調整可能なシロッコファン(日立製 PAS-RHF \#6)を直径 $0.6 \mathrm{~m}$ の丸型ダクトを用いて整流機能付・定置式複合ピ トー管センサ (ウエットマスター社製)を介して付室に接続した。ダ クト中心位置は壁端から $1.35 \mathrm{~m}$ 、床から高さ $0.6 \mathrm{~m}$ とした。

本研究では、静圧が支配的な状況注 1 を再現するため、図 3 に示寸 横 $2.44 \mathrm{~m}$ 、縦 $2.44 \mathrm{~m}$ 、厚さ $1 \mathrm{~mm}$ の多孔板(パンチングメタル)を給 気口からそれぞれ $0.9 \mathrm{~m}$ (多孔板 $\mathrm{A}$ ：穴径 $6 \mathrm{~mm}$ 、ピッチ $9 \mathrm{~mm}$ 、開 孔率 40.2\%[実質開口面積 $2.39 \mathrm{~m}^{2}$ ]) 、 $1.8 \mathrm{~m}$ (多孔板 B: 穴径 $3 \mathrm{~mm}$ 、 ピッチ $5 \mathrm{~mm}$ 、開孔率 $32.6 \%$ 〔実質開口面積 $1.91 \mathrm{~m}^{2}$ 〕)の位置に設 置した。多孔板以外の壁は厚さ $12.5 \mathrm{~mm}$ の石膏ボードとした。なお、 給気時に付室内において、隙間からの漏気試験を事前に実施したが、 多孔板以外からの空気の流出はみられなかった。

\section{2 給気条件}

本研究では前述の静圧場想定給気条件に加えて、動圧が支配的な 状況として、以下に示寸給気条件についても検討を行った。

図 4 に示すとおり、多孔板 B を取り外し、給気口を設け、給気口 以外の部分は遮蔽した。給気口寸法は幅 $1220 \mathrm{~mm}$ 、高さ $610 \mathrm{~mm}$ で あり、給気口下端が床からの高さ $1220 \mathrm{~mm}$ の場合(以下、動圧場-給 気口上部) と床に接する場合(以下、動圧場-給気口下部)の 2 条件と した。なお、給気口以外からの空気の流出はなかった。

本研究では、多孔板 A、B2 枚とも設置した場合を静圧場、多孔板 Bの代わりに給気口付きの壁を設置した場合を動圧場が再現されて いる状況と想定した。

\section{3 測定項目 \\ （1）給気風量}

給気風量は整流機能付・定置式複合ピトー管センサ (ウエットマス ター社製)により測定した。

\section{(2) 付室-外気間圧力差}

付室-外気間圧力差は、差圧計[Validyne 社製 DP103]により測定 した。図 1 に示す測定地点において、高さ $1.6 \mathrm{~m} 、 0.8 \mathrm{~m} 、 0 \mathrm{~mm}$ の

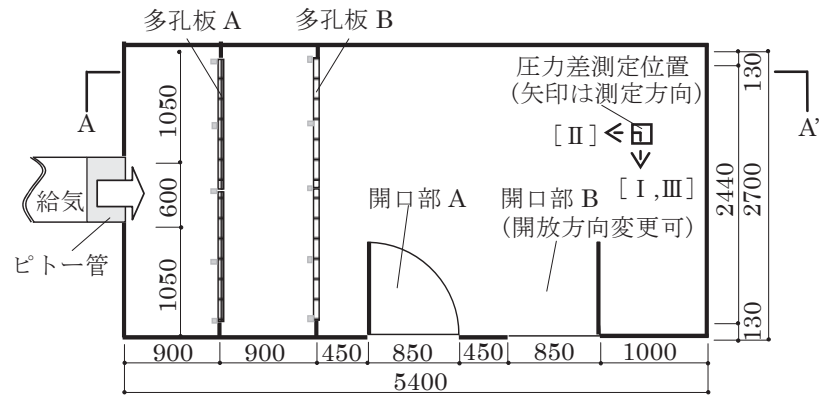

(a) 平面図

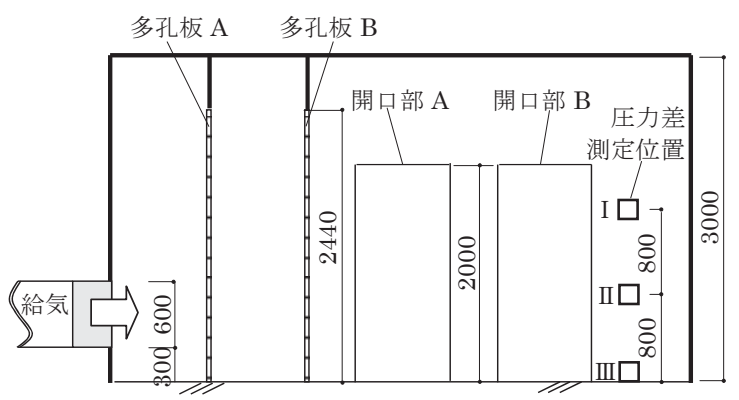

(b) A-A' 断面図

図 1 付室概要 [単位:mm]

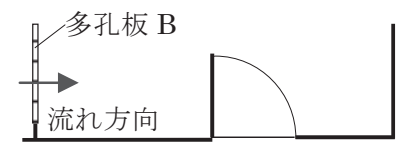

(a) 下流側開放

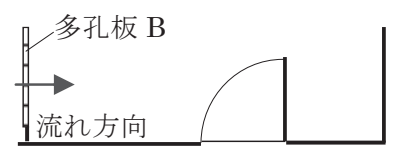

(b) 上流側開放
図 2 開放状態の定義

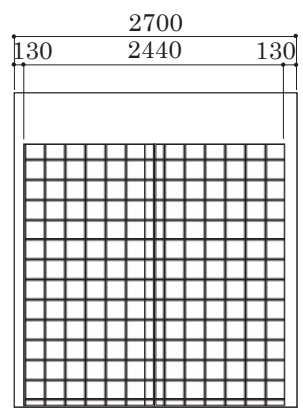

( i ) 多孔板 $\mathrm{A}$

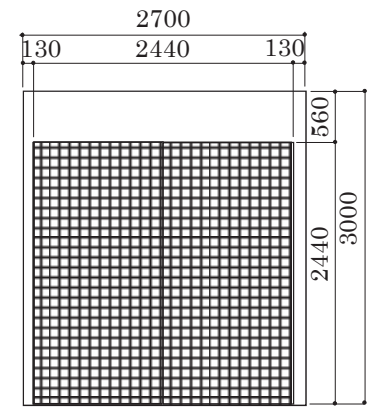

(ii) 多孔板 B （ピッチ:9 径:6 開口率 40.2\%）（ピッチ:5 径:3 開口率 32.6\%)

図 3 多孔版詳細図[単位: $\mathrm{mm}$ ]

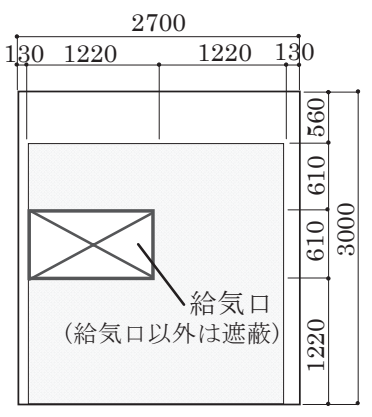

（i）動圧場-給気口上部

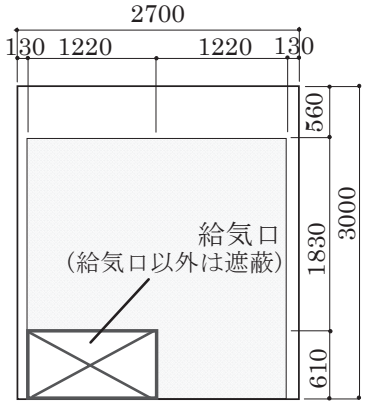

（ii）動圧場-給気口下部 図 4 動圧場の給気条件(多孔板 B)[単位:mm] 
3 ヶ所(高い方から順に I , II , III)に、直径 $6 \mathrm{~mm}$ の測定管を設置し た。測定方向(測定管の先端の向き)は、図 1 に示すとおり I 、III は 開口部方向、II は多孔板方向である。

\section{（3）垂線面風速}

常温測定時における遮煙開口部は中間的開放状態であり、得られ る測定風速は縮流のために測定面のとり方によって異なる。岸上ら 4) は扉開放角度 $\theta$ と扉開口幅の関係を構築し、扉開放幅を扉開放端 から扉板に向かって下ろした垂線でとれば、流量係数を扉角度によ らず一定として扱えることを示した。

本研究ではこの考えに従い、測定面を図 5(a)に示すとおり垂線面 とし、無指向性の熱線風速計(日本カノマックス社製 MODEL650

1、プローブ:6543-21)を用いて測定した。給気風量 $Q_{m}$ は $1.60 \mathrm{~m} / \mathrm{s}$ 程度で一定とした。なお、本実験では、扉中間的開放状態時におい てヒンジ部分に形成される隙間は完全に遮蔽した。

垂線面の分割方法を図 5(b)に示す。本研究では JIS 規定 5)に準拠 して、高さ方向に 8 分割、水平方向に 4 分割の計 32 分割とし、各 分割面の中心を代表点として測定した。なお、全条件において事前 に可視化実験を行い、垂線面において逆流の有無を確認したが、本 実験では逆流はみられなかった。

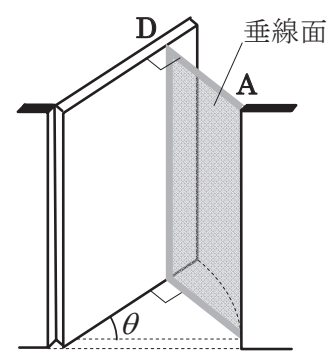

(a) 本研究で対象とする測定面

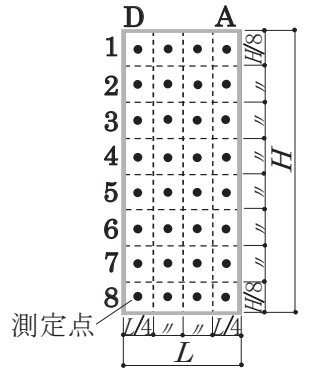

(b) 測定面分割詳細図
図 5 開口部風速測定面

\section{4 実験条件}

本実験は、給気条件、開放角度、開口位置、開放方向を変化させ、 表 1 に示寸計 21 条件の組合せについて測定を行った。

表 1 実験条件

\begin{tabular}{|c|c|c|c|c|}
\hline \multicolumn{2}{|c|}{ 給気条件 } & 開放角度 & 開口位置 & 開放方向 \\
\hline \multirow{9}{*}{\multicolumn{2}{|c|}{ 静圧場 }} & \multirow{3}{*}{$60^{\circ}$} & $\mathrm{A}$ & 下流側 \\
\hline & & & \multirow{2}{*}{ B } & 下流側 \\
\hline & & & & 上流側 \\
\hline & & \multirow{3}{*}{$45^{\circ}$} & $\mathrm{A}$ & 下流側 \\
\hline & & & \multirow{2}{*}{ B } & 下流側 \\
\hline & & & & 上流側 \\
\hline & & \multirow{3}{*}{$30^{\circ}$} & $\mathrm{A}$ & 下流側 \\
\hline & & & \multirow{2}{*}{ B } & 下流側 \\
\hline & & & & 上流側 \\
\hline \multirow{12}{*}{ 動圧場 } & \multirow{6}{*}{ 給気口上部 } & \multirow{3}{*}{$45^{\circ}$} & $\mathrm{A}$ & 下流側 \\
\hline & & & \multirow{2}{*}{ B } & 下流側 \\
\hline & & & & 上流側 \\
\hline & & \multirow{3}{*}{$30^{\circ}$} & $\mathrm{A}$ & 下流側 \\
\hline & & & \multirow{2}{*}{ B } & 下流側 \\
\hline & & & & 上流側 \\
\hline & \multirow{6}{*}{ 給気口下部 } & \multirow{3}{*}{$45^{\circ}$} & $\mathrm{A}$ & 下流側 \\
\hline & & & \multirow{2}{*}{ B } & 下流側 \\
\hline & & & & 上流側 \\
\hline & & \multirow{3}{*}{$30^{\circ}$} & $\mathrm{A}$ & 下流側 \\
\hline & & & \multirow{2}{*}{ B } & 下流側 \\
\hline & & & & 上流側 \\
\hline
\end{tabular}

\section{(1) 給気条件}

給気条件は静圧場、動圧場-給気口上部、動圧場-給気口下部の 3 条件とした。

\section{(2) 開放角度}

開放角度は、図 6 に示寸とおり $60^{\circ} 、 45^{\circ} 、 30^{\circ}$ の 3 条件とした。 ただし、動圧場は $45^{\circ} 、 30^{\circ}$ の 2 条件とした。

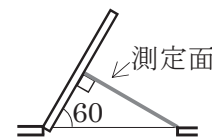

(a) $60^{\circ}$

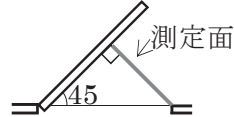

(b) $45^{\circ}$

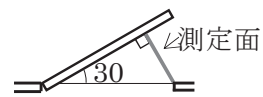

(c) $30^{\circ}$
図 6 開放角度

(3) 開口位置

開口位置は図 7 に示すとおり開口部 $\mathrm{A}$ 、開口部 $\mathrm{B}$ の 2 条件とした。

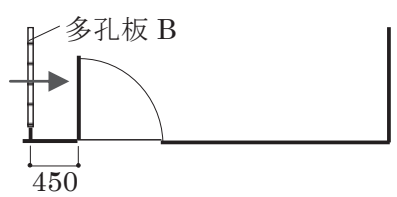

(a) 開口部 $\mathrm{A}$

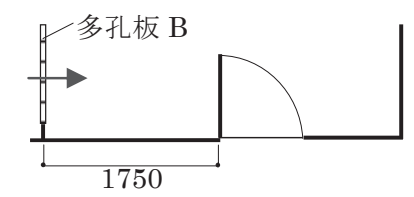

(b) 開口部 B
図 7 開口位置

\section{(4) 開放方向}

屝の開放方向は、図 8 に示寸とおり下流側開放と上流側開放の 2 条件とした。ただし、上流側開放は開口部 B のみとした。

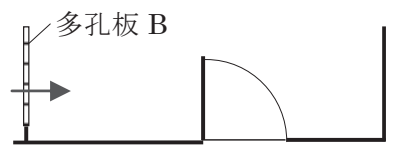

(a) 下流側開放

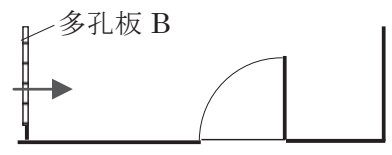

(b) 上流側開放
図 8 開放方向

\section{5 測定方法}

屝の開放状態を設定し、給気風量を一定として定常になるのを確 認した後、 1 分間測定を行った。

\section{3. 測定結果}

\section{1 静圧場再現の確認}

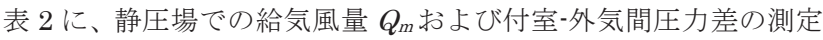
值 $\Delta P$ と 3 点の平均值を示す。開放角度 $30^{\circ}$-開口位置 $\mathrm{B}$-下流側開放 における給気風量および付室-外気間圧力差は測定できなかった。

表 2 給気風量と圧力差測定結果

\begin{tabular}{|c|c|c|c|c|c|c|c|c|}
\hline \multicolumn{4}{|c|}{ 実験条件 } & \multirow{3}{*}{$\begin{array}{c}\text { 給気風量 }\left[\mathrm{m}^{3} / \mathrm{s}\right] \\
Q_{m}\end{array}$} & \multirow{2}{*}{\multicolumn{4}{|c|}{$\frac{\text { 付室-外気間圧力差 }[\mathrm{Pa}]}{\Delta P}$}} \\
\hline \multirow{2}{*}{$\begin{array}{l}\text { 給気 } \\
\text { 条件 } \\
\end{array}$} & \multirow{2}{*}{$\begin{array}{l}\text { 開放 } \\
\text { 角度 } \\
\end{array}$} & \multirow{2}{*}{\begin{tabular}{|l|l|} 
開口 \\
位置 \\
\end{tabular}} & \multirow{2}{*}{$\begin{array}{l}\text { 開放 } \\
\text { 方向 } \\
\end{array}$} & & & & & \\
\hline & & & & & I & II & III & 平均 \\
\hline \multirow{9}{*}{$\begin{array}{l}\text { 静 } \\
\text { 圧 } \\
\text { 場 }\end{array}$} & \multirow{3}{*}{$60^{\circ}$} & A & \multirow{2}{*}{ 下流側 } & 1.63 & 2.16 & 2.13 & 2.33 & \begin{tabular}{|l|}
2.21 \\
\end{tabular} \\
\hline & & $B$ & & 1.54 & 1.93 & 1.88 & 2.00 & 1.94 \\
\hline & & & 上流側 & 1.64 & 2.14 & 2.00 & 2.17 & 2.10 \\
\hline & \multirow{3}{*}{$45^{\circ}$} & A & \multirow{2}{*}{ 下流側 } & 1.59 & 2.76 & 2.71 & 2.87 & 2.78 \\
\hline & & B & & 1.52 & 2.52 & 2.55 & 2.59 & 2.56 \\
\hline & & & 上流側 & 1.60 & 2.91 & 2.86 & 3.05 & 2.94 \\
\hline & \multirow{3}{*}{$30^{\circ}$} & A & \multirow{2}{*}{ 下流側 } & 1.54 & 5.33 & 5.29 & 5.47 & 5.36 \\
\hline & & B & & \multicolumn{5}{|c|}{ ※ } \\
\hline & & & 上流側 & 1.50 & 5.72 & 5.60 & 5.75 & 5.69 \\
\hline
\end{tabular}


表 2 より、 $\Delta P$ は各条件とも高さ、差圧測定の方向、扉の開口位 置および開放方向による違いはみられず、開放角度ごとにほぼ一定 の值を示した。これらの結果から、多孔板設置により静圧が支配的 な状況が再現できているものと考えられる。

\subsection{2 点垂線面平均風速 $\bar{V}_{p}$}

本実験で得られた垂線面上の各測定点における風速測定結果、32 点垂線面測定平均風速 $\overline{V_{p}}$ 、垂直風速 $\overline{V_{x}}$ (詳細は 4.1 参照)、給気風量 $Q_{m}$ 、標準偏差 $\sigma$ について、静圧場の場合を図 9 に、動圧場-給気口 上部の場合を図 10 に、動圧場-給気口下部の場合を図 11 に示す。

図 9 より、静圧場の場合、 $\mathrm{A}$ (開放端側)の速度が大きく、 $\mathrm{D}($ ヒン ジ側)にいくにつれて速度が小さくなる傾向を示した。これは、 $\mathrm{D}($ ヒ ンジ側)が $\mathrm{A}$ (開放端側)に比べて付室内部にあるために付室圧との圧 力差が $\mathrm{A}$ (開放端側)に比べて小さいことや、 $\mathrm{A}$ 近傍では風向が大き く傾く(後述図 14 参照)ために当該部分を通過する流体が加速する こと等が原因と考えられる。なお、鉛直方向の各測定点の風速は概 ね一定であった。

図 10、図 11 より、動圧場では特に上流側開放の場合に給気口の 位置による影響を大きく受け、給気口設置高さ付近の風速が大きく
なる。下流側開放の場合は、給気口位置による影響はやや緩和され、 $\mathrm{A}$ (開放端側)から $\mathrm{D}($ ヒンジ側)にいくにつれて速度が小さくなる。

標準偏差 $\sigma$ は、静圧場の場合は 0.23 から 0.52 を示すのに対し、 動圧場-給気口上部は 0.45 から 0.64 、動圧場-給気口上部は 0.58 か ら 1.04 を示した。このことから、測定值のばらつきは静圧場、動圧 場-給気口上部、動圧場-給気口下部の順に大きいことが分かる。

また、図 12 、図 13 に 32 点垂線面測定平均風速 $\overline{V_{p}}$ と 32 点垂線 面最大測定風速 $V_{\max } 32$ 点垂線面最小測定風速 $V_{\min }$ の関係を示寸。

図 12 より、 $V_{\max }$ と $\overline{V_{p}}$ の比は静圧場の場合、1.2 から 1.29 を示す。 一方、動圧場-給気口上部の場合は 1.33 から 1.51 、動圧場-給気口下 部の場合 1.47 から 2.17 を示し、静圧場より必ず大きい。これは、 動圧場の場合には局所的に風速が強くなる領域があるためと考えら れる。

図 13 より、 $V_{\min }$ と $\bar{V}_{p}$ の比は静圧場の場合は 0.31 から 0.6 を示す のに対し、動圧場の場合は 0.51 から 0.62 を示し、上限值について は明確な違いはみられないが、下限值については静圧場の方が小さ い值を示す。

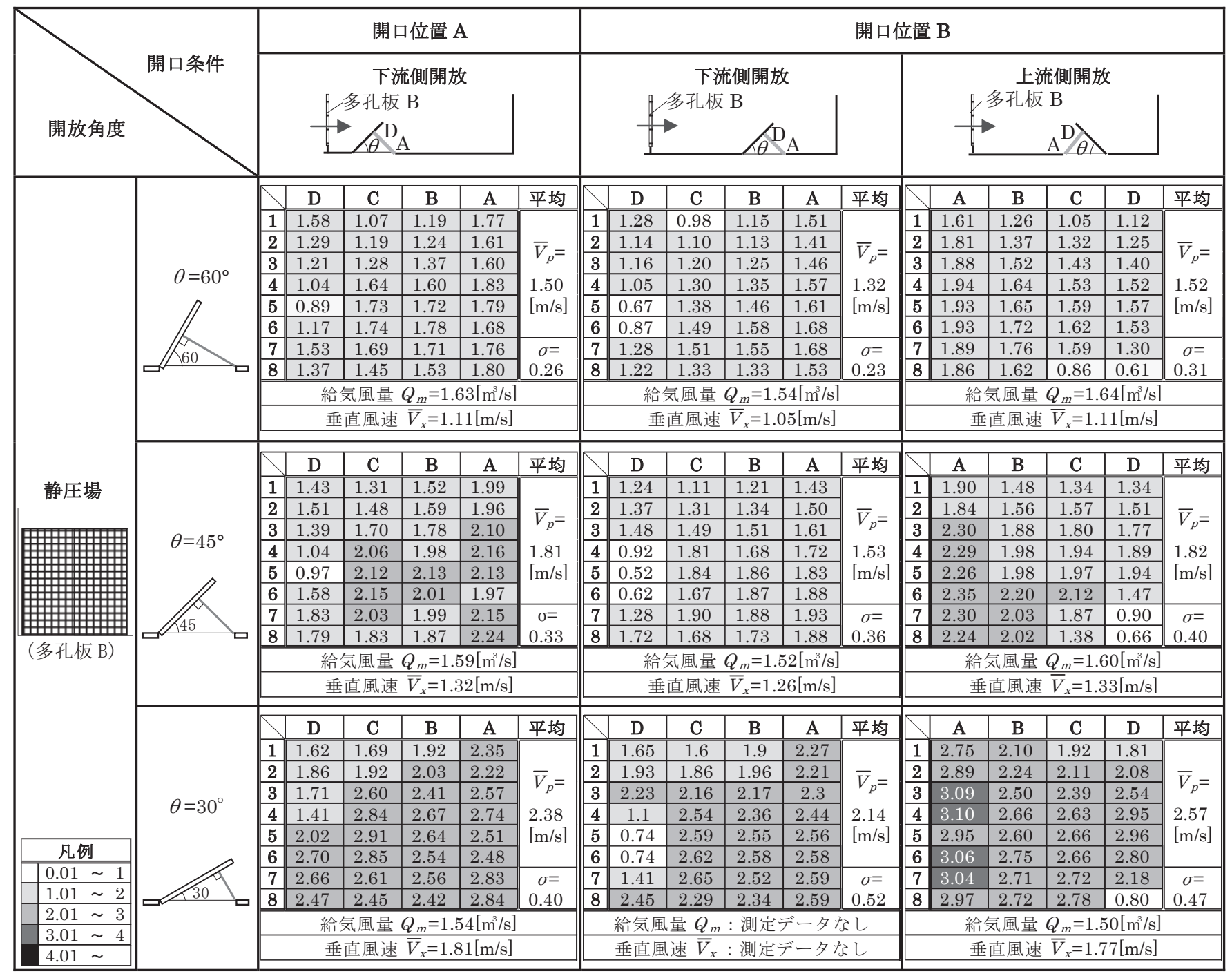

図 9 垂線面風速測定結果(静圧場) 


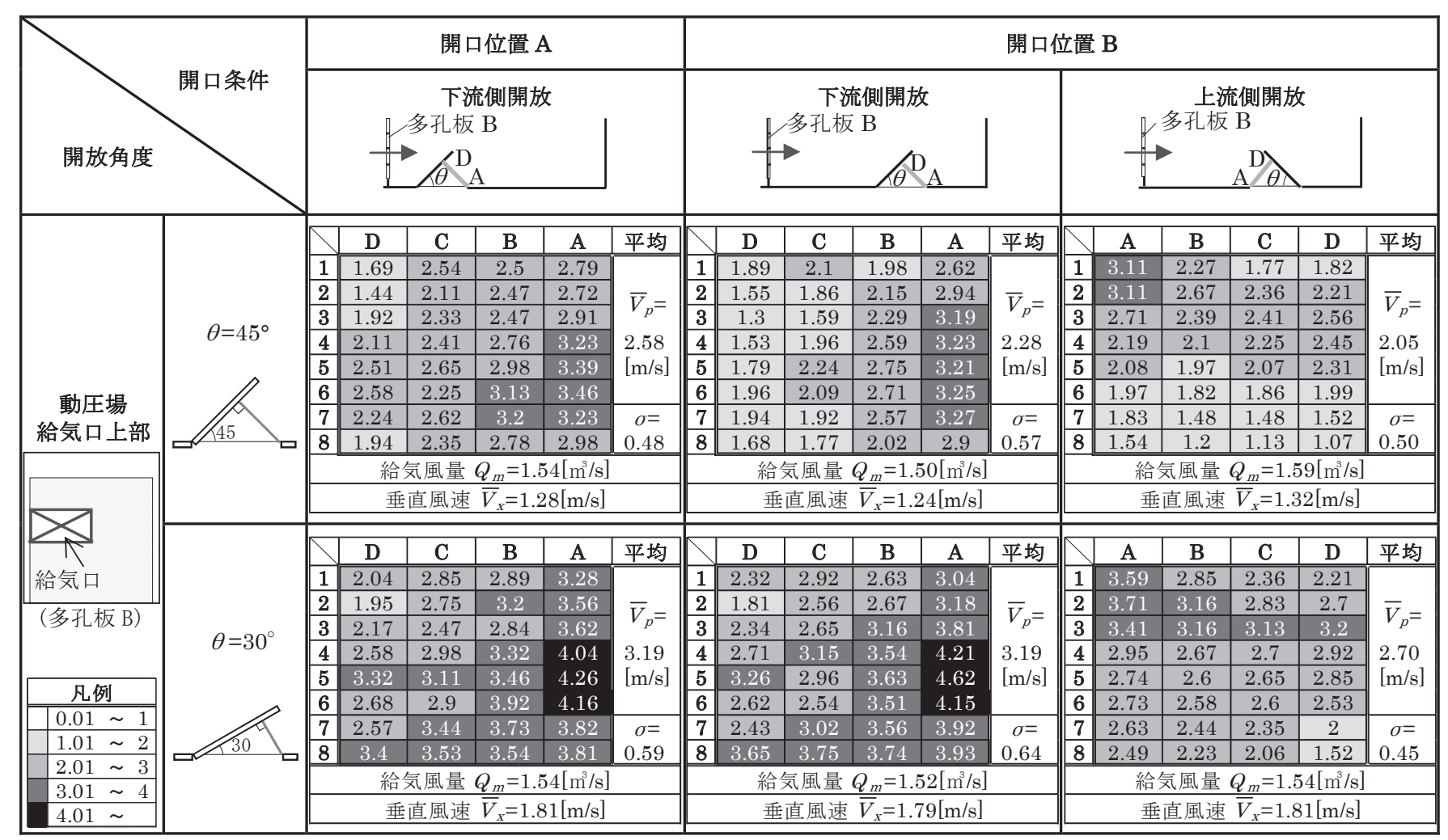

図 10 垂線面風速測定結果(動圧場-給気口上部)

\begin{tabular}{|c|c|c|c|c|c|c|c|c|c|c|c|c|c|c|c|c|c|c|c|}
\hline \multirow{2}{*}{ 開放角度 } & \multirow{2}{*}{ 開口条件 } & \multicolumn{6}{|c|}{ 開口位置 A } & \multicolumn{12}{|c|}{ 開口位置 B } \\
\hline & & & & $\begin{array}{l}\text { 下污 } \\
\text { 孔板 }\end{array}$ & 側開方 & & & & & $\begin{array}{l}\text { 下 } \\
\text { 多孔标 }\end{array}$ & 側開 & & & & & $\begin{array}{l}\text { 上泣 } \\
\text { 孔板 }\end{array}$ & 則開市 & & \\
\hline \multirow{9}{*}{$\begin{array}{c}\text { 動圧場 } \\
\text { 給気口下部 }\end{array}$} & \multirow{11}{*}{$\theta=45^{\circ}$} & & $\mathrm{D}$ & $\mathrm{C}$ & B & $\mathrm{A}$ & 平均 & & $\mathrm{D}$ & $\mathrm{C}$ & B & A & 平均 & & $\mathrm{A}$ & B & $\mathrm{C}$ & $\mathrm{D}$ & 平均 \\
\hline & & 1 & 2.55 & 2.38 & 2.45 & 2.95 & \multirow{2}{*}{$\bar{V}_{p}=$} & 1 & 2.26 & 2.36 & 2.81 & 3.54 & \multirow{3}{*}{$\bar{V}_{p}=$} & \begin{tabular}{|l|l|l}
1 & \\
\end{tabular} & 2.1 & 1.65 & 1.43 & 1.18 & \multirow{6}{*}{$\begin{array}{l}\bar{V}_{p}= \\
2.27 \\
{[\mathrm{~m} / \mathrm{s}}\end{array}$} \\
\hline & & 2 & 2.44 & 2.52 & 2.7 & 3 & & 2 & 1.98 & 2.36 & 2.77 & 3.69 & & 2 & 2.05 & 1.68 & 1.46 & 1.16 & \\
\hline & & 3 & 2.01 & 2.56 & 3.22 & 3.46 & $V_{p}=$ & 3 & 1.6 & 2.09 & 2.86 & 3.81 & & \begin{tabular}{|l|l|}
3 & \\
\end{tabular} & 1.92 & 1.64 & 1.45 & 1.34 & \\
\hline & & 4 & 1.89 & 1.91 & 3.17 & 3.71 & \multirow{3}{*}{$\begin{array}{l}2.65 \\
{[\mathrm{~m} / \mathrm{s}]}\end{array}$} & 4 & 1.58 & 2.11 & 3.09 & 4.08 & \multirow{3}{*}{$\begin{array}{l}2.74 \\
{[\mathrm{~m} / \mathrm{s}]}\end{array}$} & \begin{tabular}{|l|l|}
4 & \\
\end{tabular} & 1.9 & 1.59 & 1.45 & 1.55 & \\
\hline & & 5 & 2.19 & 1.59 & 2.62 & 3.8 & & 5 & 1.66 & 2.13 & 3.32 & 4.38 & & \begin{tabular}{|l|l|}
5 & \\
\end{tabular} & 2.36 & 1.89 & 1.48 & 1.77 & \\
\hline & & 6 & 2.22 & 1.64 & 2.93 & 3.33 & & 6 & 1.68 & 2.04 & 3.38 & 4.48 & & \begin{tabular}{|l|l|}
6 & \\
\end{tabular} & 3.66 & 2.74 & 1.8 & 2.19 & \\
\hline & & 7 & 2.17 & 1.93 & 3.01 & 2.9 & \multirow{2}{*}{\begin{tabular}{|c|}
$\sigma=$ \\
0.58 \\
\end{tabular}} & 7 & 1.67 & 1.97 & 3.35 & 4.32 & \multirow{2}{*}{$\begin{array}{c}\sigma= \\
0.90 \\
\end{array}$} & \begin{tabular}{|l|}
7 \\
\end{tabular} & 4.93 & 3.51 & 2.63 & 3.04 & \multirow{2}{*}{\begin{tabular}{|c}
$\sigma=$ \\
0.98 \\
\end{tabular}} \\
\hline & & 8 & 2.44 & 2.55 & 2.93 & 3.65 & & 8 & 1.89 & 1.95 & 2.75 & 3.76 & & \begin{tabular}{|l|l}
8 & \\
\end{tabular} & 3.5 & 4.25 & 3.81 & 3.53 & \\
\hline \multirow{4}{*}{ 給気口 } & & \multirow{2}{*}{\multicolumn{6}{|c|}{$\begin{array}{c}\text { 給気風量 } Q_{m}=1.49\left[\mathrm{~m}^{3} / \mathrm{s}\right] \\
\text { 垂直風速 } \bar{V}_{x}=1.24[\mathrm{~m} / \mathrm{s}]\end{array}$}} & \multirow{2}{*}{\multicolumn{6}{|c|}{$\begin{array}{l}\text { 給気風量 } Q_{m}=1.54\left[\mathrm{~m}^{3} / \mathrm{s}\right] \\
\text { 垂直風速 } \bar{V}_{X}=1.28[\mathrm{~m} / \mathrm{s}]\end{array}$}} & \multirow{2}{*}{\multicolumn{6}{|c|}{$\begin{array}{c}\text { 給気風量 } Q_{m}=1.63\left[\mathrm{~m}^{3} / \mathrm{s}\right] \\
\text { 垂直風速 } \bar{V}_{X}=1.36[\mathrm{~m} / \mathrm{s}]\end{array}$}} \\
\hline & & & & & & & & & & & & & & & & & & & \\
\hline & \multirow{11}{*}{$\theta=30^{\circ}$} & & $\mathrm{D}$ & $\mathrm{C}$ & B & $\mathrm{A}$ & 平均 & & $\mathrm{D}$ & $\mathrm{C}$ & B & A & 平均 & & A & B & $\mathrm{C}$ & $\mathrm{D}$ & 平均 \\
\hline & & \begin{tabular}{|l}
1 \\
\end{tabular} & 3.26 & 3.19 & 3.68 & 4.45 & \multirow{3}{*}{$\bar{V}_{p}=$} & 1 & 3.37 & 3.61 & 3.97 & 4.6 & \multirow{3}{*}{$\bar{V}_{p}=$} & $1 \mid$ & 2.61 & 2.08 & 1.87 & 1.81 & \multirow{6}{*}{$\begin{array}{l}\bar{V}_{p}= \\
2.93 \\
{[\mathrm{~m} / \mathrm{s}]}\end{array}$} \\
\hline \multirow{4}{*}{ (多孔板 B) } & & 2 & 3.04 & 3.5 & 3.66 & 4.02 & & 2 & 3.89 & 3.85 & 3.96 & 4.63 & & \begin{tabular}{|l|l|}
2 \\
\end{tabular} & 2.65 & 2.19 & 2.04 & 1.68 & \\
\hline & & \begin{tabular}{|l|}
3 \\
\end{tabular} & 2.24 & 3.83 & 4.02 & 4.19 & & 3 & 2.46 & 3.04 & 4.27 & 4.88 & & \begin{tabular}{|l|l|}
3 \\
\end{tabular} & 2.76 & 2.35 & 2.09 & 1.6 & \\
\hline & & 4 & 2.38 & 4.04 & 4.51 & 4.82 & \multirow{3}{*}{$\begin{array}{l}3.47 \\
{[\mathrm{~m} / \mathrm{s}]}\end{array}$} & 4 & 2.13 & 2.38 & 4.05 & 5.34 & \multirow{3}{*}{$\begin{array}{l}3.68 \\
{[\mathrm{~m} / \mathrm{s}]}\end{array}$} & \begin{tabular}{|l|l|l}
4 & \\
\end{tabular} & 2.85 & 2.5 & 2.34 & 2.28 & \\
\hline & & 5 & 2.16 & 2.25 & 4.07 & 5.1 & & 5 & 2.09 & 2.32 & 3.78 & 5.42 & & 5 & 3.38 & 2.83 & 2.48 & 2.28 & \\
\hline & & 6 & 2.74 & 2.33 & 3.56 & 4.54 & & 6 & 2.26 & 2.32 & 3.93 & 5.46 & & \begin{tabular}{|l|}
6 \\
\end{tabular} & 4.32 & 3.28 & 2.55 & 2.37 & \\
\hline $0.01 \sim 1$ & & 7 & 2.78 & 2.5 & 3.73 & 2.99 & $\sigma=$ & 7 & 2.47 & 2.86 & 4.76 & 3.97 & \multirow{2}{*}{$\begin{array}{c}\sigma= \\
1.04 \\
\end{array}$} & 7 & 5.34 & 4.1 & 3.33 & 3.14 & \\
\hline $1.01 \sim 2$ & & \begin{tabular}{|l} 
\\
8 \\
\end{tabular} & 3.25 & 2.92 & 3.53 & 3.74 & 0.79 & 8 & 2.67 & 3.24 & 4.79 & 4.94 & & 8 & 5.35 & 4.81 & 4.4 & 4.08 & 1.02 \\
\hline $\begin{array}{l}2.01 \sim 3 \\
3.01 \sim 4\end{array}$ & & & & 氛風量 & $\overline{2}=1$. & $9\left[\mathrm{~m}^{3} / \mathrm{s}\right]$ & & & & 風量 & $Q_{m}=1$ & $1\left[\mathrm{~m}^{3} / \mathrm{s}\right]$ & & & & 風量 & $Q_{m}=1$. & $4\left[\mathrm{~m}^{3} / \mathrm{s}\right]$ & \\
\hline $4.01 \sim$ & & & & 直風速 & $\bar{V}_{X}=1$. & $7[\mathrm{~m} / \mathrm{s}]$ & & & & 直風这 & $\bar{V}_{X}=1$ & $8[\mathrm{~m} / \mathrm{s}]$ & & & & 直風速 & $\bar{V}_{X}=1$. & $1[\mathrm{~m} / \mathrm{s}]$ & \\
\hline
\end{tabular}

図 11 垂線面風速測定結果(動圧場-給気口下部) 


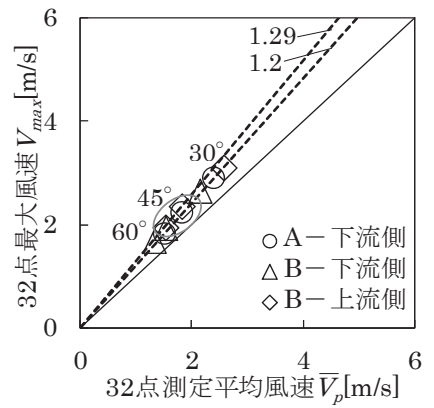

(a) 静圧場 (b) 動圧場

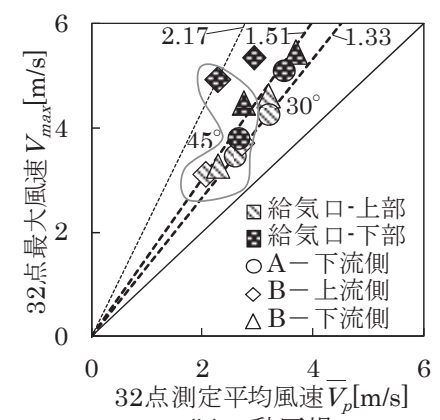

図 1232 点最大風速 $V_{\max }$ と 32 点平均風速 $\bar{V}_{p}$

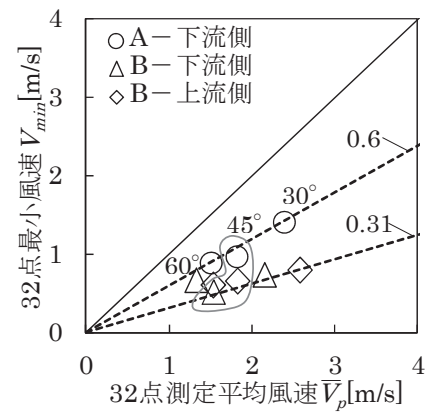

(a) 静圧場

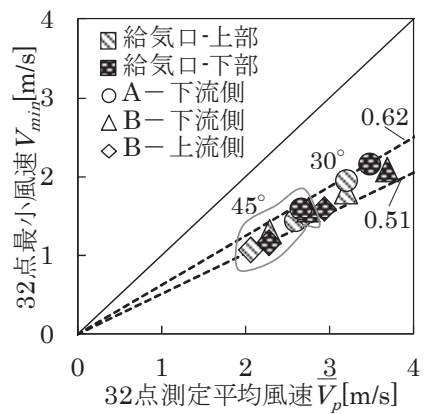

(b) 動圧場
図 1332 点最小風速 $V_{\min }$ と 32 点平均風速 $\bar{V}_{p}$

\section{32 点垂線面平均風速 $\bar{V}_{p}$ と垂直風速 $\bar{V}_{x}$}

\section{1 垂線面での速度ベクトルの直交性}

32 点垂線面平均風速 $\bar{V}_{p}$ と給気量の関係から垂線面での風速測定 值の方向性を考察する。本研究では開口以外からの漏孔はないため、 $Q_{m}$ が垂線面を通過する注 2 と考えれば、図 14 に示すとおり風速べク トルが垂線面積 $A_{p}$ に対し必ず垂直をなすとしたときの垂直風速 $\bar{V}_{x}$ は式(1)で得られる。なお、本研究では垂線面積 $A_{p}$ は扉幅 B、扉高 さ $\mathrm{H}$ とするとき、式(2)に示すとおり定義する。

$$
\begin{aligned}
& \bar{V}_{x}=\frac{Q_{m}}{A_{p}} \\
& A_{p}=B H \sin \theta
\end{aligned}
$$
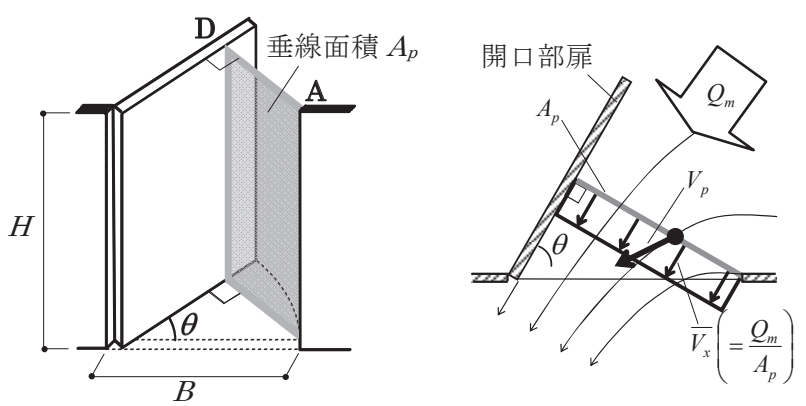

図 14 垂直風速 $\bar{V}_{x}$ の定義

図 9、10、11 に式(2)より得られる垂直風速 $\bar{V}_{x}$ を併せて示す。全 条件において $\bar{V}_{p}$ は $\bar{V}_{x}$ より必ず大きい。これは、垂線面の風速べク トルが、必ずしも垂線面に対し垂直ではないことを意味する。

\section{2 修正係数 $\xi$}

以下では、式(3)に示すとおり、32 点垂線面平均風速 $\overline{V_{p}}$ を垂直風 速 $\bar{V}_{x}$ に修正する係数(以下、修正係数) $\xi を$ 算出する。
$\xi=\frac{\bar{V}_{x}}{\bar{V}_{p}}$

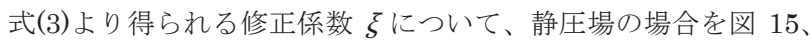
動圧場の場合を図 16 に示寸。なお、 $\bar{V}_{p} 、 \bar{V}_{x}$ は図 9、10、11 に示し た值を用いた。

静圧場の場合、図 15 より そは開放角度、開口位置、開放条件に よらずおおむね定の值を示す。本研究では平均 0.75 、最大 0.83 、 最小 0.69 を示し、1 より必ず小さい。したがって、式(4)に示すとお り、 $\bar{V}_{p}$ に 0.69 を乗じた值を $\bar{V}_{x}$ と扱えば必ず実際の垂直風速より小 さい。

$$
\bar{V}_{x} \geq 0.69 \bar{V}_{p}
$$

動圧場の場合、図 16 より $\xi$ は給気条件、開放条件、開口位置に より大きく異なる。本研究では平均 0.55 、最大 0.67 、最小 0.46 が 得られ、必ず静圧場の場合より小さい。これは垂線面風速べクトル が静圧場より傾いていることを意味する。

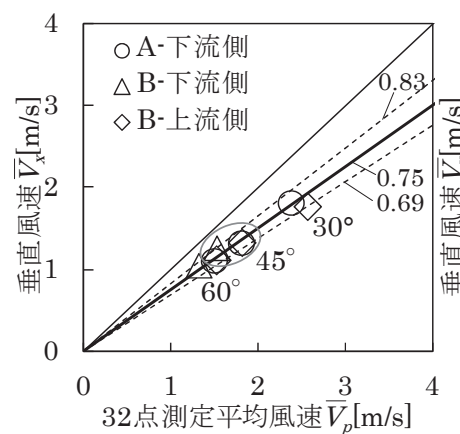

図 15 修正係数 $\xi$ (静圧場)

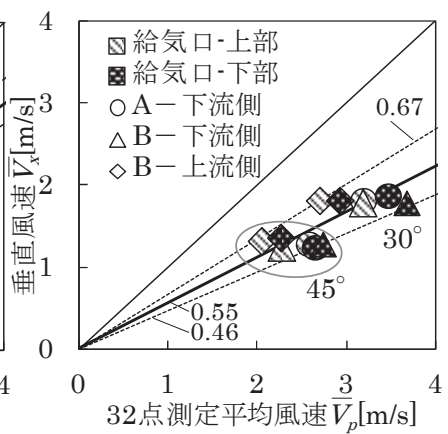

図 16 修正係数 $\xi$ (動圧場)

\section{5. 測定点数についての検討}

これまで 32 点測定平均風速と垂直風速の関係を構築してきたが、 測定の手間を考えると、32 点より少ない測定点数(以下、代表点)で 遮煙開口部の風速を安全側で把握できれば有用である。

よって、以下では 32 点測定平均風速より必ず小さい風速值を算出 するための風速比率を、代表点の測定平均風速に乗じることで安全 側となる代表点風速測定についての検討を行う。

式(5)に示すとおり、代表点測定平均風速 $\bar{V}_{R}$ を 32 点測定平均風速 $\bar{V}_{p}$ に補正する係数を風速比率 $\eta$ と定義する。

$$
\eta=\frac{\bar{V}_{p}}{\bar{V}_{R}}
$$

代表点は、図 17 に示す 9 点、 8 点、 4 点、 2 点、 1 点の計 5 条件 について検討した。なお、各代表点は、本研究で測定した 32 点と 測定位置が異なるため、本研究では図 18 に示寸とおり、32 点測定 值のうち当該代表点に面寸る 4 点の最大值を、各代表点風速 $\overline{V_{R}}$ と して代用した。なぜなら、測定結果(図 9、10、11)からわかるとお り、32 点分割においても隣接する測定点の風速測定值にも大きな違 いがみられる箇所があることを踏まえて、代表点測定值がその分割 面における実際の平均風速よりも大きな值を測定してしまう危険性 を考慮したためである。

全実験条件の風速比率 $\eta$ の分布を代表風速点数毎に図 18 に示寸。 図 18 より、代表点 8 点の $\eta$ の分布は代表点 9 点の場合とおお屯 䃿等しく、0.84 から 0.91 の值をとる。本研究では、32 点測定平均 風速より必ず小さい風速值を算出する最小風速比率を明らかにする 
ことが目的であるから、 8 点の場合の最小風速比率は 0.84 となる。 そのため、給気条件や開口条件によっては最大 $8 \%(=1-0.84 / 0.91)$ 風 速を小さく評価する状況が起こりうる。

また、代表点を 4 点、 2 点、 1 点と減らすと $\eta$ のばらつきが大き くなり、風速を小さく評価する割合は 4 点の場合は最大で $11 \%(=1-0$. 87/0.98)、 2 点の場合は最大 $17 \%(=1-0.81 / 0.98) 、 1$ 点の場合は最大 $36 \%(=1-0.77 / 1.2)$ となる。

以上を踏まえて、風速を最大 $8 \%$ 程度過小評価することを許容す れば、式(5)に示すとおり代表点 8 点測定平均風速 $\bar{V}_{8}$ 点に最小風速比 率 0.84 を乗じた值を 32 点測定平均風速 $\overline{V_{p}}$ として扱えば安全側と 考えられる。

$\bar{V}_{p} \geq 0.84 \bar{V}_{8 \text { 点 }}$

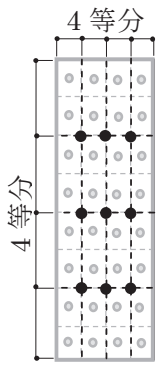

(a) 9 点

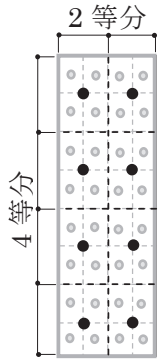

(b) 8 点

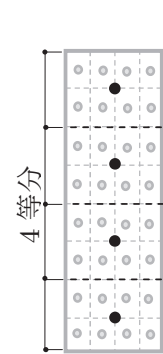

(c) 4 点

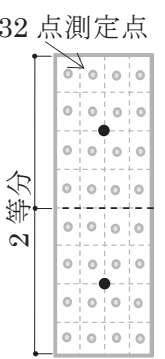

(d) 2 点

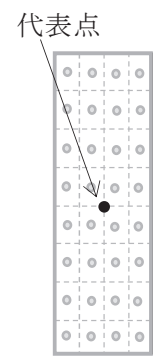

(e) 1 点
図 17 本研究で対象とした測定点数

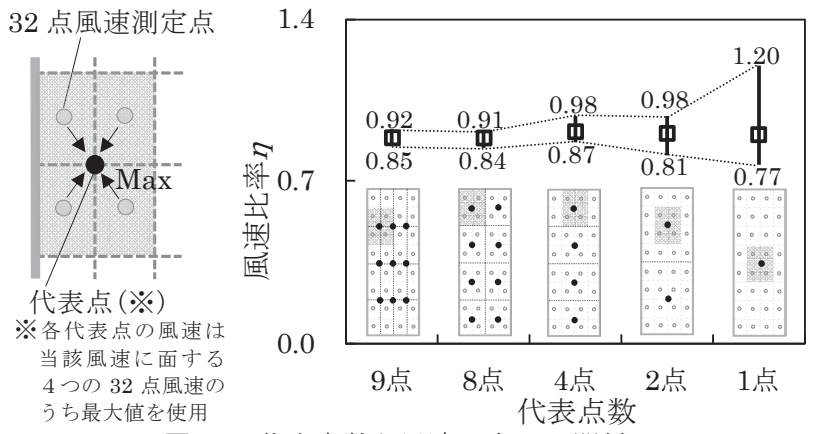

図 18 代表点数と風速比率 $\eta$ の関係

\section{6. 代表点測定風速 $\bar{V}_{R}$ と垂直風速 $\bar{V}_{x}$ の関係}

32 点測定平均風速 $\overline{V_{p}}$ と代表点測定平均風速 $\overline{V_{R}}$ の関係は式(5)よ り次式で得られる。

$\bar{V}_{p}=\eta \bar{V}_{R}$

32 点測定平均風速 $\bar{V}_{p}$ と垂直風速 $\bar{V}_{x}$ の関係は式(3)より次式で得 られる。

$$
\bar{V}_{x}=\xi \bar{V}_{p}
$$

よって、式(7)および式(8)から $\bar{V}_{R}$ と $\bar{V}_{x}$ の関係は次式で与えられる。 $\bar{V}_{x}=\xi \eta \bar{V}_{R}$

例えば静圧場の場合、代表点 8 点平均風速 $\bar{V}_{8}$ 点 垂直風速 $\bar{V}_{x}$ の

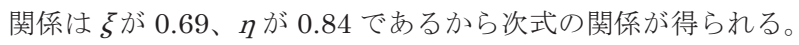

$\bar{V}_{x} \geq 0.69 \times 0.84 \bar{V}_{8 \text { 点 }}=0.58 \bar{V}_{\text {点 }}$

式(10)は、垂線面での代表点 8 点平均風速 $\bar{V}_{8}$ 点に 0.58 を乗じた值 を垂直風速として評価すればよいことを意味する。

\section{7. まとめ}

加圧煙制御の性能を常温時に確認するために必要な垂線面測定風
速と垂線面に対する垂直風速の関係を明らかにすることを目的とし て、開口部扉が設置された実大付室において、常温給気時における 中間的開放性状 $\left(30^{\circ} \leqq \theta \leqq 60^{\circ}\right)$ の場合の付室-外気間圧力差、給気風 量を測定した。また、無指向性の風速計により垂線面風速測定を行 った。その結果、以下のことを示した。

1）垂線面風速べクトルは必ずしも垂線面に垂直ではない。

2) 32 点垂線面測定風速 $\bar{V}_{p}$ を垂直風速 $\bar{V}_{x}$ に修正する係数 $\xi\left(\bar{V}_{x}=\right.$ $\left.\xi \overline{V_{p}}\right)$ は、静圧場では平均 0.75 、最大 0.83 、最小 0.69 を示し、 扉開放角度、開口位置、開放方向によらずおおむ救一定である。

3）乡は、動圧場では開口位置、開放方向に影響を受け、本研究の 範囲内では平均 0.55 、最大 0.67 、最小 0.46 を示す。

4）風速を最大 $8 \%$ 程度過小評価することを許容するなら、代表点 8 点測定平均風速 $\bar{V}$ 点に 0.84 を乗じた值を 32 点測定平均風速 $\overline{V_{p}}$ として扱える。

\section{謝辞}

本研究は平成 24 年度東京理科大学「灭災安全科学研究拠点」共 同利用・共同研究として実施されたものである。記してここに謝意 を示します。

\section{補足 1}

以下では、静圧場条件で測定した付室-外気間圧力差 $\Delta \mathrm{P}$ を用いて、扉口面 積 $A_{g}$ (図 $\mathrm{A} 1(\mathrm{a})$ 参照)に対する流量係数 $\alpha_{g}$ および垂線面積 $A_{p}$ (図 $\mathrm{A} 1(\mathrm{~b})$ 参照)に 対する流量係数 $\alpha_{p}$ を算出する。

なお、通常の扉は厚さを有し、 $\alpha$ もその影響を受けると思われるが、本研 究の $\alpha$ 算出においては一般的な $\alpha$ の取り扱いと同様に扉厚を無視した。扉幅 $B$ 、扉高さ $H$ 、扉角度 $\theta$ とするとき、屝口面積 $A_{g}$ 、垂線面積 $A_{p}$ はそれぞ れ以下の式で示される。

$$
\begin{aligned}
& A_{g}=B H \\
& A_{p}=B H \sin \theta
\end{aligned}
$$

(補足. 2)

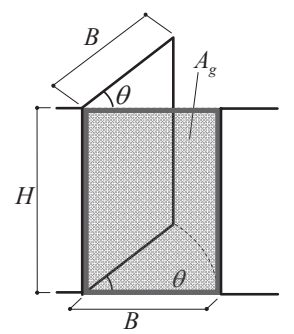

（a）扉口面積 $A$

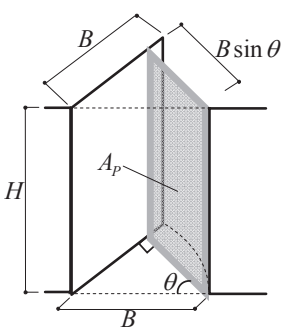

(b) 垂線面積 $A_{p}$
図 A1 対象と寸る開口面積の取り方

本実験では開口部以外からの空気の流出は見られなかったため、開口部流 量 $Q$ として給気風量 $Q_{m}$ を用いると、実験で得られた $Q_{m} 、 \Delta P$ から扉口面積 $A_{g}$ に対する流量係数 $\alpha_{g}$ は式(補足.3)で算出される。

$$
\alpha_{g}=\frac{Q_{m}}{A_{g}} \sqrt{\frac{\rho}{2 \Delta P}}
$$

同様に垂線面積 $A_{p}$ に対する流量係数 $\alpha_{p}$ は式(補足.4)で算出される。

$\alpha_{p}=\frac{Q_{m}}{A_{p}} \sqrt{\frac{\rho}{2 \Delta P}}$

(補足.4)

また、式(3)と式(4)の関係より、 $\alpha_{p}$ と $\alpha_{g}$ の関係は次式となる。

$\alpha_{p}=\alpha_{g} \frac{A_{g}}{A_{p}}=\frac{\alpha_{g}}{\sin \theta}$

(補足.5)

本研究で得られた測定結果を式(補足.3)および式(補足.4)に代入して得られ る $\alpha_{g} 、 a_{p}$ を表 $\mathrm{A} 1$ に示す。また、既往の研究として広田らにより提案された 式(以下、広田式)上り得られる $\alpha_{g}{ }^{6}$ ) 洋3) とそれを式(補足.5)に代入して得られる $\alpha_{p}$ を併せて示す。

表 $\mathrm{A} 1$ より、扉口面積 $\mathrm{A}_{\mathrm{g}}$ に対する流量係数 $\alpha_{g}$ は、開口位置、開放方向によ 


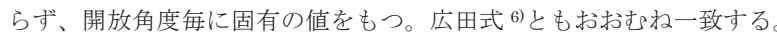
垂線面積 $\mathrm{A}_{\mathrm{p}}$ に対寸る流量係数 $\alpha_{p}$ は、開放角度、開口位置、開放条件によ らず 0.58 から 0.62 の值を示した。これは垂線面積に対する流量係数を扉角 度によらず一定と扱えることを意味し、岸上らの考え ${ }^{4)}$ と一致する。

表 $\mathrm{A} 1$ 流量係数 $\alpha_{g}$ および $\alpha_{p}$

\begin{tabular}{|c|c|c|c|c|c|c|c|c|}
\hline \multicolumn{3}{|c|}{ 実験条件 } & \multicolumn{2}{|c|}{ 開口面積 $\left[\mathrm{m}^{2}\right]$} & \multicolumn{4}{|c|}{ 流量係数 } \\
\hline \multirow{2}{*}{$\begin{array}{l}\text { 開放 } \\
\text { 角度 } \\
\end{array}$} & \multirow{2}{*}{ 開口 } & \multirow{2}{*}{$\begin{array}{l}\text { 開放 } \\
\text { 方向 } \\
\end{array}$} & \multirow{2}{*}{$A_{g}$} & \multirow{2}{*}{$A_{p}$} & \multicolumn{2}{|c|}{$\alpha_{g}$} & \multicolumn{2}{|c|}{$\alpha_{p}$} \\
\hline & & & & & 本研究 & 広田 ${ }^{6)}$ & 本研究 & 広田 ${ }^{6)}$ \\
\hline \multirow{3}{*}{$60^{\circ}$} & A & \multirow{2}{*}{ 下流側 } & \multirow{9}{*}{1.70} & \multirow{3}{*}{1.47} & 0.50 & \multirow{3}{*}{0.53} & 0.58 & \multirow{3}{*}{0.62} \\
\hline & \multirow{2}{*}{ B } & & & & 0.51 & & 0.58 & \\
\hline & & 上流側 & & & 0.52 & & 0.60 & \\
\hline \multirow{3}{*}{$45^{\circ}$} & A & \multirow{3}{*}{\begin{tabular}{|l|} 
下流側 \\
上流側 \\
\end{tabular}} & & \multirow{3}{*}{1.20} & 0.44 & \multirow{3}{*}{0.45} & 0.62 & \multirow{3}{*}{0.63} \\
\hline & \multirow{2}{*}{ B } & & & & 0.43 & & 0.61 & \\
\hline & & & & & 0.42 & & 0.60 & \\
\hline \multirow{3}{*}{$30^{\circ}$} & $\mathrm{A}$ & \multirow{3}{*}{\begin{tabular}{|l|}
$\mid$ \\
上流测側 \\
\end{tabular}} & & \multirow{3}{*}{0.85} & 0.30 & \multirow{3}{*}{0.33} & 0.61 & \multirow{3}{*}{0.66} \\
\hline & $B$ & & & & $※$ & & $※$ & \\
\hline & & & & & 0.29 & & 0.58 & \\
\hline
\end{tabular}

\section{補足 2}

告示の扉開放幅における解釈の一つとして、垂線を $40 \mathrm{~cm}$ とする考えのほ かに図 A2(a)に示すように遮蔽板等により扉口幅を $40 \mathrm{~cm}$ に縮小する方法も 考えられる。本論文では静圧場-開口位置 B-上流側開放の条件のみであるがこ の考えについても検討した。

$5500 \mathrm{~m}^{3} / \mathrm{h}\left(1.53 \mathrm{~m}^{3} / \mathrm{s}\right)$ の給気風量を投入したときの扉口面風速を 32 分割して 測定した結果を図 $\mathrm{A} 2(\mathrm{~b})$ に示す。測定結果より、修正係数 $=0.74$ が得られた。 また、補足 1 同様、測定した付室-外気間圧力差を用いて得られる扉口面積 $(=0.4 \mathrm{H}$ 〔H:扉高さ〕) に対する流量係数 $\alpha$ は 0.64 であった。

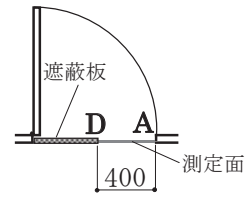

(a) 測定面

\begin{tabular}{|c|c|c|c|c|c|}
\hline & $\mathrm{D}$ & $\mathrm{C}$ & B & A & 平均 \\
\hline 1 & 3.2 & 2.7 & 2.5 & 2.68 & \multirow{3}{*}{$\bar{V}_{p}=$} \\
\hline 2 & 3.05 & 2.3 & 2.29 & 2.68 & \\
\hline 3 & 2.93 & 2.45 & 2.29 & 2.6 & \\
\hline 4 & 3 & 2.5 & 2.32 & 2.67 & \multirow{3}{*}{$\begin{array}{l}2.59 \\
{[\mathrm{~m} / \mathrm{s}]}\end{array}$} \\
\hline 5 & 1.47 & 2.58 & 2.36 & 2.56 & \\
\hline 6 & 2.44 & 2.49 & 2.32 & 2.53 & \\
\hline 7 & 3.14 & 2.63 & 2.5 & 2.71 & $\sigma=$ \\
\hline 8 & 3.11 & 2.61 & 2.48 & 2.73 & 0.32 \\
\hline \multicolumn{6}{|c|}{ 給気風量 $Q_{m}=1.53\left[\mathrm{~m}^{3} / \mathrm{s}\right]$} \\
\hline \multicolumn{6}{|c|}{ 垂直風速 $\bar{V}_{X}=1.92[\mathrm{~m} / \mathrm{s}]$} \\
\hline
\end{tabular}

(b) 風速測定結果 [単位: $\mathrm{m} / \mathrm{s}$ ]
図 A2 扉口幅 $40 \mathrm{~cm}$ 時の風速測定結果
注2）現実には扉上部の扇形の面積(以下、上部面)からの流れも存在すると考 えられるが、本研究では、以下に示す点を考慮して、上部面の流れを無 視する取り扱いとした。

(1)本研究では、垂線面風速ベクトルが垂線面に対し垂直か否かを明ら かにすることが目的であり、開口部流量 Q が垂線面を全て通過する と考えたときに、得られる垂直風速は最も大きい值を示すこと

(2)本研究では、常温給気時における垂線面平均風速と垂直風速(流量を 測定面積で除した垂直風速) との関係の構築であり、垂線面積 $A_{p}$ を 基準に考え、垂線面風速を垂直風速に修正する係数 $\xi$ を設定する扱 いとしても問題はないこと

注3）広田らは、扉幅 $0.765 \mathrm{~m}$ 、扉高さ $2.58 \mathrm{~m}$ 、給気口-扉間距離 $10 \mathrm{~m}$ によ る実験を行い、流量係数の実験回帰式として下式を提案した。ただし、 この式は開放端側から回転軸までの長さ $(0.765 \mathrm{~m})$ に扉高さを乗じた面 積に対する流量係数である。本研究では、扉幅に扉高さを乗じた扉口面 積に対する流量係数を用いたため、既往式を 0.96 倍 $(=0.765 / 0.8)$ した。 $\alpha=0.023+0.0125 \theta-0.000060 \theta^{2}$

（2013年 4 月10日原稿受理， 2013年 7 月 12 日採用決定）

\section{参考文献}

1）久次米真美子, 松下敬幸, 田中㫴義：附室加圧煙制御システムにおける給 気量の手計算方法, 日本建築学会計画系論文集第 531 号, pp.1-8, 2000.5

2) 松下敬幸, 藤田浩司, 岸上昌史, 高田暁: 常温での測定による加圧煙制御 システムの適切さの確認方法, 日本建築学会環境系論文集第 645 号, pp.1203-1209, 2009.11

3）松下敬幸, 岸上昌史, 藤田浩司, 高田暁 : 加圧煙制御の遮煙開口部におけ る流量測定に関する研究-模型実験による外開き扉の常温時における簡易 流量測定法-, 日本建築学会近畿支部研究報告集, pp.309-312, 2011

4）岸上昌史, 松下敬幸, 藤田浩司, 高田暁: 加圧煙制御における常温換気計 算法に基づく給気量算定法及び空気逃し開口部の設置高さの影響, 日本建 築学会環境系論文集 673 号, pp.115-120, 2012.3

5）日本工業標準調查会：JIS B 8330 送風機の試験及び検查方法，2000

6）広田正之, 松山賢, 山名俊男, 若松孝旺: 防排煙時の圧力差予測のための 中間的開放扉の基本特性，日本建築学会環境系論文集 602 号 pp.1-8, 2006.4

7）社団法人日本建築学会， : 技術資料 管路・ダクトの流体抵抗, pp.109-113, 2008

注

注1）本研究では静圧が支配的な状況を作るためには、速度分布を均一化する ことが重要と考え、既往の研究 7)を参考として多孔板寸法を決定し、付 室-外気間圧力差測定によりその性能を確認した。 